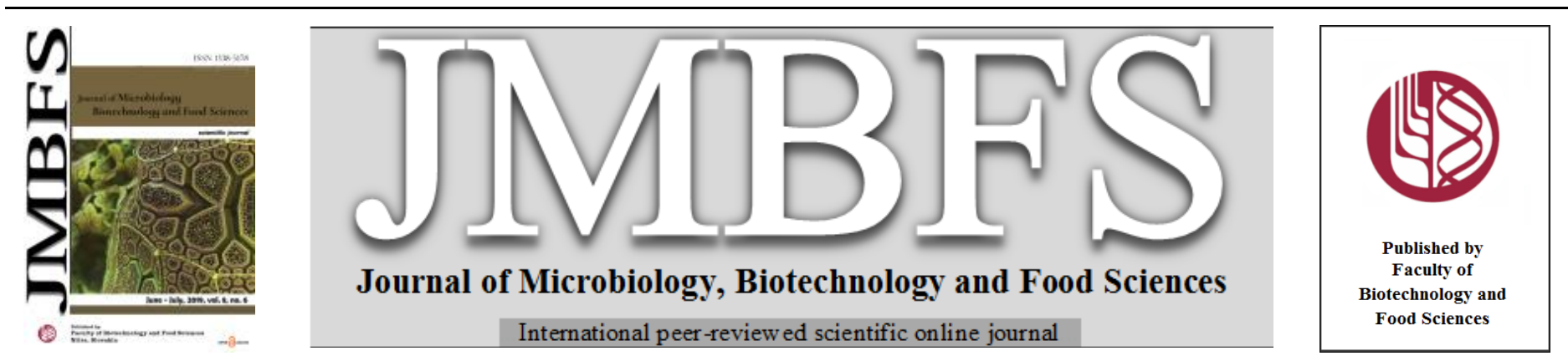

\title{
CHEMICAL COMPOSITION, ANTIOXIDANT ACTIVITY AND MINERAL CONTENT OF ARBUTUS UNEDO (LEAVES AND FRUITS)
}

\author{
Noureddine Asmaa ${ }^{1}$, Gherib Abdelaziz ${ }^{1}$,Bakchiche Boulanouar ${ }^{1}$, Ángel A. Carbonell-Barrachina, ${ }^{2,}$, Marina Cano-Lamadrid ${ }^{2}$, and \\ Luis Noguera-Artiaga ${ }^{2}$
}

Address(es):

${ }^{1}$ Laboratory Process Engineering, Ammar Telidji University, B.P. 37G, Laghouat 03000, Algeria.

${ }^{2}$ Agro-Food Technology Department, Universidad Miguel Hernandez de Elche, Orihuela, Alicante, Spain, Ctra. De Beniel, km 3,2, 03312-Orihuela, Alicante, Spain.

*Corresponding author: angel.carbonell@umh.es

doi: 10.15414/jmbfs.2019.8.6.1335-1339

\section{ARTICLE INFO}

Received 12. 2. 2019

Revised 31. 3. 2019

Accepted 9. 4. 2019

Published 1. 6. 2019

Regular article

open $\partial_{\text {ACCESS }}$

\begin{abstract}
Arbutus unedo is widely used in traditional medicine and is an easily accessible source of natural antioxidants to replace synthetic antioxidants. The bioactive compounds and antioxidant activity of the leaves and fruits extracts (after maceration and sonication) were studied. The mineral analyses exhibited large quantities of many essential minerals in fruits and leaves, especially interesting were the levels of macronutrients ( $\mathrm{K}$ and $\mathrm{Ca}$ ) in fruits and micronutrients $(\mathrm{Fe})$ in leaves. The GC-MS analysis of essential oils of leaves and fruits led to the identification of 32 and 35 compounds, respectively. The major components in leaves were camphor, cymenene, and bornyl acetate, and in fruits, camphor, ethyl palmitate and bornyl acetate. The extraction method significantly affected the contents of total phenolics and total flavonoids, with the maceration method rendering the best results in leaves and the sonication in fruits. All maceration extracts had the highest antioxidant activity (assayed by 3 methods DPPH', ABTS ${ }^{+}$and FRAP; besides, A. unedo leaves showed higher activity than fruits. As a conclusion, it can be stated that Arbutus unedo is a plant rich in polyphenols, volatile compounds, and minerals, and that it can be used as a potential source of bioactive compounds, especially from the leaves.
\end{abstract}

Keywords: Camphor, Ericaceae family, essential oil, iron, maceration, potassium, sonication

\section{INTRODUCTION}

The study of new sources of natural antioxidants is constantly increasing because of the growing consumer demand for natural products and the interest for medicinal and nutritional plants to avoid the use of synthetic antioxidants because of their carcinogenic effect, among other factors. Medicinal plants are the source of natural antioxidants thanks to their main secondary metabolites, mainly polyphenols and essential oils (Bursal and Köksal, 2010; Aidi Wissem et al., 2010).

The biological effects of phenolic compounds found in fruits are very wide and include antiallergic, antibacterial, anticarcinogenic, antiinflammatory, antithrombotic, antiviral, cardioprotective, hepatoprotective, and vasodilatory effects. Essential oils are very important in plant defense processes and, also have proved health benefits. In addition, they are use as raw materials or ingredients in many fields, such as the agro-food, cosmetics, and pharmaceutical industries. The beneficial effects of both polyphenols and essential oils have been mainly attributed to their antioxidant capacity which acts controlling two reaction types i) the transfer of hydrogen atoms and ii) the transfer of a single electron (Benhammou et al., 2009; Zuzarte and Salgueiro, 2015).

Arbutus unedo L. is a plant from the Ericaceae family, which is an evergreen shrub or small tree (Isbilir et al., 2012), and diverse medicinal properties have been attributed to its fruits, leaves, roots, and/or bark. Some of the uses of its leaves are as follows: i) the leaves of A. Unedo are used as antihypertensive, urinary antiseptic, astringent, depurative, against blennorrhagia and as antidiarrheal; and, ii) a tea prepared from its leaves is also used as diuretic. However, the use of the fruits of A. Unedo is very limited, despite its high contents of nutrients and bioactive compounds (Orak et al., 2011).

Consequently, the objectives of this study were first to determine the profiles of the essential oils of Arbutus unedo (leaves and fruits) and their mineral content, and secondly to study the influence of the different extraction methods on polyphenol content and antioxidant activity of the extracts.

\section{MATERIAL AND METHODS}

\section{Plant material}

The leaves and fruits of A. Unedo were collected in November of 2015, in the Natural Forest of Tiaret (west of Algeria). The plant material was stored at room temperature in a dry place until used. The dried leaves and fruit were ground to get a fine powder. All analyses were run in triplicate.

\section{Mineral content analysis by atomic absorption-emission spectrometry}

The contents of mineral elements ( $\mathrm{Ca}, \mathrm{Mg}, \mathrm{K}, \mathrm{Na}, \mathrm{Cu}, \mathrm{Fe}, \mathrm{Mn}$ and $\mathrm{Zn}$ ) in dried leaves (Ar-L) and fruits (Ar-Fr) of A. Unedo were analyzed using Unicam Solaar 969 atomic absorption spectrometer (Unicam Limited, Cambridge, UK), after the digestion with concentrated $\mathrm{HNO}_{3}$ (Garcia-Garcia et al., 2013).

\section{Extraction of the essential oil}

The essential oils of the dried samples of leaves and fruits of A. Unedo were extracted by hydrodistillation using the Deryng apparatus, as previously used in thyme (Calín-Sánchez et al., 2013). Approximately $30 \mathrm{~g}$ of sample were extracted and vapors containing the volatile fractions were concentrated in $1 \mathrm{~mL}$ of cyclohexane. After $30 \mathrm{~min}$ of extraction, the solvent containing the volatile compounds was recuperated and stored at $4{ }^{\circ} \mathrm{C}$ until further analyses were conducted.

\section{Chromatographic analyses}

The volatile composition of the A. Unedo essential oils were analyzed by GC-MS using a Shimadzu GC-17A gas chromatograph (Shimadzu Corporation, Kyoto, Japan), coupled with a Shimadzu GC-MS QP-5050A mass spectrometer detector. A TRACSIL Meta.X5 column was used and the chromatographic conditions were those previously reported (Calín-Sánchez et al., 2013). Identification was based on retention indexes, retention time of authentic standards, and mass spectra (authentic chemicals and Wiley 229 spectral library), and was considered 
tentative when only based on comparison with mass spectra (Hojjati $\boldsymbol{e t}$ al., 2013).

After the identification, each volatile compound was quantified (relative abundance \%) in a Shimadzu 2010 gas chromatograph equipped with a flame ionization detector (FID); the same column and similar chromatographic conditions to those previously reported for GC/MS were used.

\section{Polyphenol extraction}

Extraction by a hydro-alcoholic mixture. Approximately $1 \mathrm{~g}$ of plant material was mixed and macerated in a hydro-alcoholic solution (methanol/water at a ratio of $80 / 20 \mathrm{v} / \mathrm{v}$ ) for $24 \mathrm{~h}$ at darkness and continuous stirring. The macerate was filtered and the solvent evaporated under vacuum at $40^{\circ} \mathrm{C}$. Later, hexane was used to remove any traces of non-polar compounds (pigments, lipids, etc.). Finally, phenolic compounds were extracted using ethyl acetate containing ammonium sulfate $(20 \%)$ and orthophosphoric acid (2\%). The extraction was repeated 3 times to ensure complete removal of the phenolic compounds and the organic phase was evaporated using the previously described conditions. Finally, the residue was dissolved in $10 \mathrm{~mL}$ of methanol and stored at $4^{\circ} \mathrm{C}$ (Amiot et al., 1986).

Extraction by sonication. Briefly, $0.5 \mathrm{~g}$ of plant material were extracted using 10 $\mathrm{mL}$ of $80 \%$ aqueous methanol containing $1 \% \mathrm{HCl}$. This mixture was sonicated twice for $20 \mathrm{~min}$, and left for $24 \mathrm{~h}$ at $4^{\circ} \mathrm{C}$. Then, the extract was centrifuged and the supernatant was collected and used for the analyses of total phenolic content and antioxidant capacity (Nuncio-Jáuregui et al., 2015; Chong et al., 2013).

\section{Total phenolic content (TPC)}

The total phenolic content (TPC) in the leaves and fruit extracts of A. Unedo was quantified using the Folin-Ciocalteu reagent and saturated sodium carbonate. The mixture was incubated at room temperature under dark conditions and absorbance at $765 \mathrm{~nm}$ was measured. A calibration curve was prepared using gallic acid (Figure 1A), and TPC was expressed as mg gallic acid equivalents, GAE/g dry weight, dw (Benhammou et al., 2009).

\section{Total flavonoid content (TFC)}

The Dowd method as adapted by Djabou et al. (2013) was used to quantify the total flavonoid content (TFC), and used aluminum trichloride in ethanol; the absorbance at $430 \mathrm{~nm}$ was recorded. A calibration curve was prepared using rutin (Figure 2B), and TFC was expressed as mg rutin equivalents, RE/g dw.

\section{Antioxidant capacity}

The DPPH' Radical Scavenging Assay was run according to Brand-Williams $\boldsymbol{e}$ al. (1995) with slight modifications. The absorbance was measured at $517 \mathrm{~nm}$, and vitamin $\mathrm{C}$ and BHA were used as control standards. The antioxidant capacity was expressed by the IC50 value in $\mathrm{mg} / \mathrm{mL}$; that is, the concentration of the sample required for a 50\% inhibition, with lower IC50 values indicating higher antioxidant capacity.

The $\mathrm{ABTS}^{+}$Radical Scavenging Assay was measured according to Re et al. (1999). The absorbance was measured at $734 \mathrm{~nm}$, and results were expressed as Trolox Equivalent Antioxidant Capacity, TEAC; that is, the Trolox concentration necessary to obtain the same radical ABTS+ inhibition than $1 \mathrm{mg} / \mathrm{mL}$ of the extract under study (Montoro et al., 2006)

The Ferric Reducing Power was measured according to Gülçin et al. (2010), which is based on the direct reduction of $\mathrm{Fe}^{3+}\left(\mathrm{CN}^{-}\right)_{6}$ to $\mathrm{Fe}^{2+}\left(\mathrm{CN}^{-}\right)_{6}$. The absorbance at $700 \mathrm{~nm}$ was monitored, expressed as TEAC, and vitamin $\mathrm{C}$ and BHA were used as controls (Gursoy $\boldsymbol{e t}$ al., 2009).
A

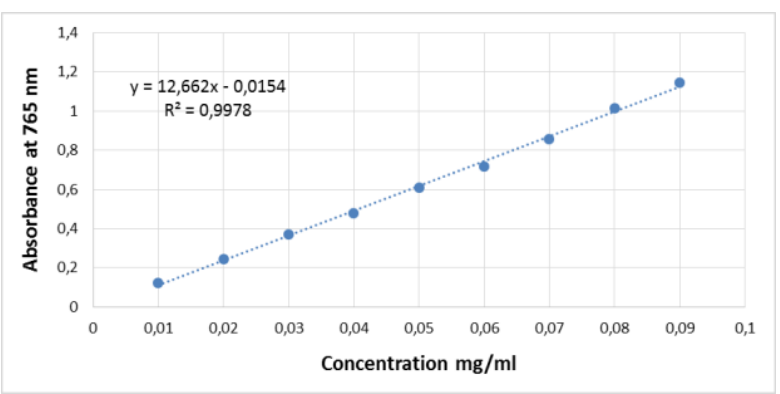

B

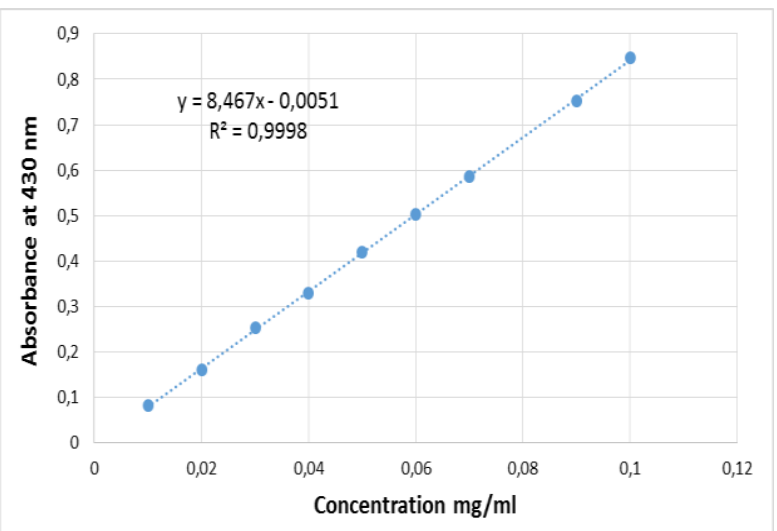

Figure 1 Calibration curves of A: gallic acid (TPC, total phenolic content), and B: rutin (TPC, total flavonoid content).

\section{Statistical analyses}

One-way analysis of variance (ANOVA) and Tukey's multiple range test were performed to compare experimental data and determine significant differences among treatments $(p<0.05)$.

\section{RESULTS AND DISCUSSION}

\section{Minerals content}

Among the macro-nutrients, K (1743 and $2045 \mathrm{mg} / 100 \mathrm{~g}$ ) and $\mathrm{Ca}$ (1299 and 1797 $\mathrm{mg} / 100 \mathrm{~g}$ ) predominated in both leaves and fruits, respectively (Table 1). On the other hand, the values of $\mathrm{Mg}$ were low, as compared to those of $\mathrm{K}$ and $\mathrm{Ca}$, reaching values of 186 and $58.6 \mathrm{mg} / 100 \mathrm{~g}$ in leaves and fruits, respectively. The "fruits" of A. Unedo have attained the highest concentrations of most macronutrients except Mg. However, the leaves had higher contents of 3 of the micro-nutrients $(\mathrm{Fe}, \mathrm{Zn}$, and $\mathrm{Mn}$ ) than fruits, and besides $\mathrm{Fe}$ was the most abundant micro-nutrient in both leaves and fruits. Results from the current study were higher than the values reported in Spanish (Ruiz-Rodríguez et al., 2011) Turkish (Özcan and Haciseferogullan, 2007) and Moroccan (Mrabti et al., 2017) samples of this same tree. In all scientific references (Ruiz-Rodríguez $\boldsymbol{e} t$ al., 2011; Özcan and Haciseferogullan, 2007; Mrabti et al., 2017), K was the main macro-element followed by $\mathrm{Ca}$ in fruits and leaves of $\mathrm{A}$. Unedo; regarding the micro-elements, Fe predominated in all samples from the different countries.

Table 1 Mineral contents of leaves (Ar-L) and fruits (Ar-Fr) of Arbutus Unedo, expressed as mg/100 g dried weigh (dw).

\begin{tabular}{lcc}
\hline & $\boldsymbol{A r}-\boldsymbol{L}$ & $\boldsymbol{A r}-\boldsymbol{F r}$ \\
\hline Macro-elements (mg/100 g dw) & & \\
\hline $\mathrm{Ca}$ & $1298 \pm 96^{*} \mathrm{~b}^{\ddagger}$ & $1797 \pm 53 \mathrm{a}$ \\
$\mathrm{Na}$ & $24.7 \pm 4.9 \mathrm{~b}$ & $43.5 \pm 2.5 \mathrm{a}$ \\
$\mathrm{Mg}$ & $186 \pm 4 \mathrm{a}$ & $58.6 \pm 3.4 \mathrm{~b}$ \\
$\mathrm{~K}$ & $1743 \pm 14 \mathrm{~b}$ & $2045 \pm 119 \mathrm{a}$ \\
\hline Micro-elements (mg/100 g dw) & & \\
\hline $\mathrm{Fe}$ & $26.8 \pm 0.5 \mathrm{a}$ & $7.02 \pm 0.2 \mathrm{~b}$ \\
$\mathrm{Zn}$ & $3.8 \pm 0.1 \mathrm{a}$ & $1.9 \pm 0.1 \mathrm{~b}$ \\
$\mathrm{Cu}$ & traces & $1.5 \pm 0.1$ \\
$\mathrm{Mn}$ & $1.1 \pm 0.1 \mathrm{a}$ & $0.3 \pm 0.1 \mathrm{~b}$ \\
\hline
\end{tabular}

${ }^{\dagger}$ Values are expressed as mean \pm standard deviation of 3 replicates. ${ }^{t}$ Values followed by the same letter, within the same row, were not significantly different ( $p<0.05)$, according to Tukey's least significant difference test. 
Table 2 Chemical composition of the leaves oil of Arbutus unedo $\mathrm{L}$.

\begin{tabular}{|c|c|c|c|c|c|}
\hline & Compound & RT $^{\ddagger}$ (min) & $\mathbf{R I ^ { ¥ } ( \operatorname { e x p } )}$ & Leaves (\%) & Fruits (\%) \\
\hline 1 & $\alpha$-Fenchone & 9.03 & 1418 & $17.5^{\dagger} \mathrm{a}$ & $1.51 \mathrm{~b}$ \\
\hline 2 & Cymenene & 10.02 & 1448 & 0.48 & 0.29 \\
\hline 3 & Linalool oxide & 10.06 & 1450 & 0.72 & 1.30 \\
\hline 4 & Salvene & 10.32 & 1458 & 0.17 & 0.03 \\
\hline 5 & $(Z, Z)-2,4$-Heptadienal & 10.83 & 1473 & 0.97 & 0.85 \\
\hline 6 & Fenchyl acetate & 11.00 & 1478 & 1.72 & 2.04 \\
\hline 7 & $\alpha$-Ylangene & 11.42 & 1491 & 0.78 & 0.61 \\
\hline 8 & $(E, E)-2,4$-Heptadienal & 11.74 & 1501 & $1.61 \mathrm{a}$ & $0.12 \mathrm{~b}$ \\
\hline 9 & Camphor & 12.54 & 1524 & $43.5 \mathrm{a}$ & $37.6 \mathrm{~b}$ \\
\hline 10 & Linalool & 13.45 & 1550 & 0.71 & 0.40 \\
\hline 11 & 1-Octanol & 13.78 & 1560 & 0.41 & 0.26 \\
\hline 12 & Pinocarvone & 14.26 & 1574 & 0.36 & 0.26 \\
\hline 13 & Bornyl acetate & 14.69 & 1586 & $16.0 \mathrm{a}$ & $12.9 \mathrm{~b}$ \\
\hline 14 & Caryophyllene & 15.28 & 1603 & 0.16 & 0.13 \\
\hline 15 & Terpinen-4-ol & 15.38 & 1606 & 0.87 & 0.80 \\
\hline 16 & Myrtenal & 16.33 & 1632 & 0.47 & 0.23 \\
\hline 17 & (E)-2-Decenal & 16.94 & 1649 & $0.60 \mathrm{a}$ & $0.19 \mathrm{~b}$ \\
\hline 18 & Pinocarveol & 17.24 & 1657 & $0.36 \mathrm{a}$ & $0.16 \mathrm{~b}$ \\
\hline 19 & Myrtenyl acetate & 18.53 & 1693 & 3.16 & 2.58 \\
\hline 20 & $\alpha$-Terpineol & 18.81 & 1701 & 0.52 & 0.44 \\
\hline 21 & Eucarvone & 18.89 & 1703 & 3.16 & 3.12 \\
\hline 22 & $\delta$-Carvone & 20.13 & 1737 & 0.80 & 0.60 \\
\hline 23 & 2-Methylacetophenone & 21.59 & 1777 & 0.16 & 0.10 \\
\hline 24 & Cuminal & 21.84 & 1783 & $0.17 \mathrm{a}$ & $0.03 \mathrm{~b}$ \\
\hline 25 & Myrtenol & 22.27 & 1795 & 0.50 & 0.38 \\
\hline 26 & Anethole & 23.59 & 1832 & nd & 0.93 \\
\hline 27 & $m$-Cymen-8-ol & 24.22 & 1849 & 0.55 & 0.45 \\
\hline 28 & $p$-Cymen-8-ol & 24.36 & 1853 & 0.44 & 0.64 \\
\hline 29 & Neryl acetone & 24.71 & 1863 & $1.03 \mathrm{a}$ & $0.06 \mathrm{~b}$ \\
\hline 30 & $\beta$-Ionone & 27.54 & 1943 & $0.21 \mathrm{a}$ & $0.06 \mathrm{~b}$ \\
\hline 31 & Ethyl myristate & 31.68 & 2061 & nd & 1.31 \\
\hline 32 & Viridiflorol & 32.54 & 2088 & $0.38 \mathrm{a}$ & $0.07 \mathrm{~b}$ \\
\hline 33 & 2-Hexadecanone & 34.30 & 2141 & 0.56 & nd \\
\hline 34 & Nonanoic acid & 35.70 & 2184 & 0.92 & 0.66 \\
\hline 35 & Methyl palmitate & 37.30 & 2234 & nd & 5.64 \\
\hline 36 & Ethyl palmitate & 38.55 & 2274 & nd & 23.3 \\
\hline
\end{tabular}

\section{Volatile compounds}

A total of 36 compounds were found in both leaves and fruits of A. Unedo (32 and 35 in leaves and fruits, respectively (Table 2). The 5 major components in leaves were: camphor $(43.5 \%)$, $\alpha$-fenchone $(17.5 \%)$, bornyl acetate $(16.0 \%)$, myrtenyl acetate $(3.16 \%)$, and eucarvone $(3.16 \%)$. On the other hand, the 5 major compounds in fruits were: camphor (37.6\%), ethyl palmitate (23.3\%), bornyl acetate (12.9\%), and methyl palmitate (5.64\%). The chemical composition of $A$. Unedo essential oils reported here was different from those reported previously in samples from Turkey and Portugal. In the Turkish leaves, it was found that $(E)-2-$ decenal and $\alpha$-terpineol predominated (Kivcak et al., 2001), while in fruits the most abundant compounds were (Z)-3-hexen-1-ol, 1-hexanol, hexanal, (E)-2hexenal, (Z)-3-hexenyl acetate and hexyl acetate (Oliveira et al., 2011). These differences on composition may be related to different factors such as harvesting season, growth cycle of the plant, as well as region and even extraction method (Berka-Zougali et al., 2010). The Portuguese samples were collected in the Natural Park of Monteshinho in the region of Trás-os-Montes (North-eastern Portugal), were rain is abundant and plants grow wild and without any cultural intervention (Oliveira et al., 2011); while the Turkish samples were collected from West Anatolia in Izmir-Cicekliköy, but not further information is provided about growing or climatic conditions (Kivcak et al., 2001).

Total phenolic (TPC) and flavonoid (TFC) contents
It is clear from data on Table 3 that the leaves of A. Unedo have higher TPC (expressed as mg GAE/g) and TFC (expressed as mg RE/g) than the fruits. In leaves, the maceration method was more efficient for TPC and higher values were reached, while results in TFC were equivalent and no effect of the extraction method was found. In fruits, the sonication method was more effective for both TPC and TFC.

The sonication extraction was previously studied and was found more effective for the extraction of phenolic compounds than the classical maceration (Balouir et al., 2014), but this extraction under the current experimental conditions did not give good results for the leaves, although results were better for the fruits.

It has been established that prolonged sonication is not recommended for the extraction of antioxidant bioactive components, as it may lead to the degradation of the active constituents (Annegowda et al., 2010). Thus, the in future studies,

the extraction time can be optimized to get the highest possible TPC, if that is the only objective of the extraction.

The high contents of both TPC and TFC obtained in the current extracts of $A$. unedo were similar to those previously reported in other studies (Boulanouar $\boldsymbol{e t}$ al., 2013; Orak et al., 2011; Mendes et al., 2011), even though different extraction techniques were used. Mendes et al. (2011) confirmed that the leaves extract had 10 times higher TPC than that of the fruit extract.

Table 3 Total phenolic content (TPC, expressed as mg gallic acid equivalents, GAE/g) and total flavonoid content (TFC, expressed as mg rutin equivalents, RE/g) of leaves (Ar-L) and fruits (Ar-Fr) of Arbutus Unedo.

\begin{tabular}{lcccc}
\hline & \multicolumn{2}{c}{ TPC (mg GAE/g) } & \multicolumn{2}{c}{ TFC (mg RE/g) } \\
\hline \multicolumn{1}{c}{ Extraction method } & Maceration & Sonication & Maceration & Sonication \\
\hline Leaves (Ar-L) & $175.4 \pm 1.3 \mathrm{a}$ & $100.2 \pm 3.0 \mathrm{~b}$ & $65.2 \pm 0.7 \mathrm{a}$ & $66.5 \pm 1.2 \mathrm{a}$ \\
Fruits (Ar-F) & $13.2 \pm 0.6 \mathrm{~b}$ & $34.3 \pm 1.9 \mathrm{a}$ & $0.4 \pm 0.1 \mathrm{~b}$ & $2.1 \pm 0.1 \mathrm{~b}$ \\
\hline${ }^{\prime}$ Values (mean of 3 replications) followed by the same letter, for the same plant part (leaves or fruits) \\
and same parameter (TPC or TFC), were not significantly different ( $p>0.05)$, Tukey's least significant \\
difference test.
\end{tabular}




\section{Antioxidant capacity}

The antioxidant capacity of the A. Unedo extracts was tested using three different methods (DPPH', $\mathrm{ABTS}^{+}$, and FRAP). The extract showed an interesting antioxidant activity, and the effect of the extraction method and part of the plant under study (leaves or fruits) showed similar behavior (Table 4). In the DPPH the leaves extract obtained by maceration led to the lowest values of the IC50, meaning it had the highest antioxidant activity. On the other hand, the lowes IC50 for the $\mathrm{DPPH}^{*}$ was found in fruits after sonication. In fact, the antioxidant activity (DPPH') of the leaves extract was equivalent to that of vitamin $\mathrm{C}$ and higher than that of BHA.
In the other two methods $\left(\mathrm{ABTS}^{+}\right.$and FRAP), the highest antioxidant activity (highest values of TEAC) were found for the macerated extracts of the leaves of A. unedo. However, both standards (vitamin $\mathrm{C}$ and BHA) showed significantly higher activity than the plant extracts assayed. A good correlation between antioxidant activity and TPC has been widely reported (17), as is indicated by high correlation coefficients, $\mathrm{R}^{2}$; in this particular case, values of $\mathrm{R}^{2}=-0.2827$ 0.9118 , and 0.8107 were found for $\mathrm{DPPH}^{\circ}, \mathrm{ABTS}^{+}$, and FRAP, respectively. These results agreed with previous results (28) and (31).

Table 4 Antioxidant capacities of leaves (Ar-L) and fruits (Ar-Fr) of Arbutus Unedo, determined by radical scavenging assay (DPPH') expressed as IC50\% $(\mu \mathrm{g} / \mathrm{mL})$, and Trolox Equivalent Antioxidant Capacity, TEAC (ABTS $\left.{ }^{+}\right)$and Ferric Reducing Antioxidant Power (FRAP) expressed as TEAC

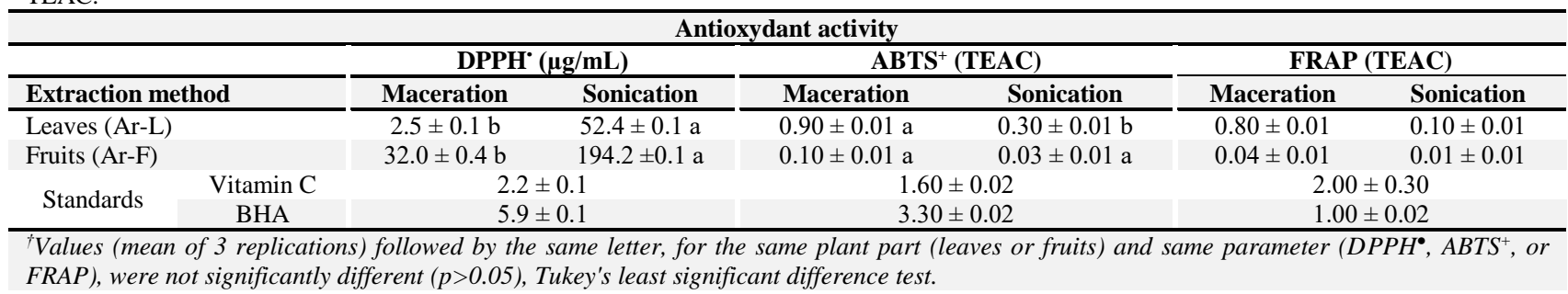

\section{CONCLUSION}

Fruits and leaves contained large quantities of many essential minerals and trace element. GC-MS analyses of essential oils of leaves and fruit allowed the identification of 32 and 35 compounds, respectively. Under the assayed conditions, the maceration was an effective method for the extraction of phenolic compounds. Experimental results demonstrated that A. Unedo leaves extracts exhibited much higher antioxidant activity than fruits.

Acknowledgments: The authors would like to thank all number of the department of Agro-Food Technology (Miguel Hernández University (Spain)) especially Luis Noguera Artiaga, Marina Cano Lamadrid, and the Agricultural engineer, Francisca Hernández García from the department of Plant Production and Microbiology E.P.S, for their help valuable and also all number of pedagogical laboratory of the department of Science of matter (Laghouat University (Algeria)).

\section{REFERENCES}

AIDI WISSEM, W., MHAMDI, B., SRITI, J., BEN JEMIA, M., OUCHIKH, O., HAMDAOUI, G., KCHOUK, M.E., MARZOUK, B. 2010. Antioxidant activities of the essential oils and methanol extracts from myrtle (Myrtus communis var. italica L.) leaf, stem and flower. Food and Chemical Toxicology, 48, 362-1370. https://doi.org/10.1016/j.fct.2010.03.002

AMIOT, M.J., FLEURIET, A., MACHEIX, J.J. 1986. Importance and evolution of phenolic compounds in olive during growth and maturation. Journal of Agricultural and Food Chemistry, 34, 823-826. DOI: 10.1021/j00071a014 ANNEGOWDA, H.V., ANWAR, L.N., MORDI, M.N., RAMANATHAN, S , MANSOR, S.M.K. 2010. Influence of sonication on the phenolic content and antioxidant activity of Terminalia catappa L. leaves. Pharmacognosy Research, 2, 368-373. http://www.phcogres.com/text.asp?2010/2/6/368/75457

BALOUIRI, M., SADIKI, M., OUEDRHIRI, W., FARAH, A., EL ABED, S., KORAICHI, A.K. 2014. Antibacterial activity of extracts from Salvia officinalis and Rosmarinus officinalis obtained by sonication and maceration methods International Journal of Pharmacy and Pharmaceutical Sciences, 6, 167-170. BENHAMMOU, N., BEKKARA, F.A., PANOVSKA, T.K. 2009. Antioxidan activity of methanolic extracts and some bioactive compounds of Atriplex halimus. Comptes Rendus Chimie, 12, 1259-1266. https://doi.org/10.1016/j.crci.2009.02.004

BERKA-ZOUGALI, B., HASSANI, A., BESOMBES, C., ALlAF, K. 2010 Extraction of essential oils from Algerian myrtle leaves using instant controlled pressure drop technology. Journal of Chromatography A, 1217, $6134-6142$ https://doi.org/10.1016/j.chroma.2010.07.080

BOUlanOUAR, B., ABDElaZIZ, G., SMAIL, A., GAGOB, C., MIGUEL, M.G. 2013. Antioxidant activities of eight Algerian plant extracts and two essential oils. Industrial Crops and Products, 46, 85-96. https://doi.org/10.1016/j.indcrop.2013.01.020

BRAND-WILLIAMS, W., CUVELIER, M.E., BERSET, C. 1995. Use of a free radical method to evaluate antioxidant activity. Food Science and Technology, 28, 25-30. https://doi.org/10.1016/S0023-6438(95)80008-5

BURSAL, E., KÖKSAL, E. 2011. Evaluation of reducing power and radical scavenging activities of water and ethanol extracts from sumac (Rhus coriaria L.). Food Research International, 44, 2217-2221. https://doi.org/10.1016/j.foodres.2010.11.001
CALÍN-SÁNCHEZ, A., FIGIEL, A., LECH, K, SZUMNY, A., CARBONELLBARRACHINA, AA. 2013. Effects of drying methods on the composition of thyme (Thymus vulgaris L.) essential oil. Drying Technology, 31, 224-235. https://doi.org/10.1080/07373937.2012.725686

DJABOU, N., EL AMINE, M.D., ALLALI, H., BENDERB, A., KAMAL, M. GHALEM, S., TABTI, B. 2013. Evaluation of antioxidant and antimicrobial activities of the phenolic composition of Algerian Arbutus unedo L. roots. Pharmacognosy Journal, $\quad 5, \quad 275-280$. https://doi.org/10.1016/j.phcgj.2013.09.003

GARCIA-GARCIA, E., NARBONA, E., CARBONELL-BARRACHINA, A.A. SANCHEZ-SORIANO, J., ROCHE, E. 2013. The effect of consumption of inulin-enriched turrón serum lipids over a 5-week period. International Journal of Food Science and Technology, 48, 405-411. https://doi.org/10.1111/j.13652621.2012.03202.x

GUERREIRO, A.C., GAGO, C.M.L., MIGUEL, M.G.C., ANTUNES, M.D.C. 2013. The effect of temperature and film covers on the storage ability of Arbutus unedo L. fresh fruit. Scientia Horticulturae, 159, 96-102. https://doi.org/10.1016/j.scienta.2013.04.030

GÜlÇIN. I,, BURSAL, E., SEHITOGLU, M.H., BILSEL, M., GÖREN, A.C 2010. Polyphenol contents and antioxidant activity of lyophilized aqueous extract of propolis from Erzurum, Turkey. Food and Chemical Toxicology, 48, 2227 2238. https://doi.org/10.1016/j.fct.2010.05.053

GURSOY, N., SARIKURKCU, C., CENGIZ, M., SOLAK, M.H. 2009 Antioxidant activities, metal contents, total phenolics and flavonoids of seven Morchella species. Food and Chemical Toxicology, 47, 2381-2388 https://doi.org/10.1016/j.fct.2009.06.032

HOJJATI, M., CALÍN-SANCHEZ, A., RAZAVI, S.H., CARBONELLBARRACHINA, A.A. 2013. Effect of roasting on colour and volatile composition of pistachios (Pistacia vera L.). International Journal of Food Science and Technology, 48, 437-443. https://doi.org/10.1111/j.1365 2621.2012.03206.x

CHONG, C.H., LAW, C.L., FIGIEL, A., WOJDYŁO, A., OZIEMBŁOWSKI M. 2013. Colour, phenolic content and antioxidant capacity of some fruits dehydrated by a combination of different methods. Food Chemistry, 141, 38893896. https://doi.org/10.1016/j.foodchem.2013.06.042

ISBILIR, S.S., ORAK, H.H., YAGAR, H., NESLIHAN, E. 2012. Determination of antioxidant activities of strawberry tree (Arbutus unedo L.) flowers and fruits at different ripening stages. Acta Scientiarum Polonorum Hortorum Cultus, 11, 223-237.

MALHEIRO, R., SÁ, O., PEREIRA, E., AGUIAR, C., BAPTISTA, P., PEREIRA, J.A. 2012. Arbutus unedo L. leaves as source of phytochemicals with bioactive properties. Industrial Crops and Products, 37, 473-478. https://doi.org/10.1016/j.indcrop.2011.07.023

MENDES, L., DE FREITAS, V., BAPTISTA, P., CARVALHO, M. 2011. Comparative antihemolytic and radical scavenging activities of strawberry tree (Arbutus unedo L.) leaf and fruit. Food and Chemical Toxicology, 49, 22852291. https://doi.org/10.1016/i.fct.2011.06.028

MONTORO, P., TUBEROSO, C.I.G., PIACENTE, S., PERRONE, A., DE FEO V., CABRAS, P., PIZZA, C. 2006. Stability and antioxidant activity of polyphenols in extracts of Myrtus communis L. berries used for the preparation of myrtle liqueur. Journal of Pharmaceutical and Miomedical Analysis, 41, 1614 1619. https://doi.org/10.1016/j.jpba.2006.02.018

MRABTI, H.N., MARMOUZI, I., SAYAH, K., CHEMLAL, L., EL OUADI, Y., ELMSELlEM, H., CHERRAH, Y., FAOUZI, M.A. 2017. Arbutus unedo L aqueous extract is associated with in vitro and in vivo antioxidant activity. 
Journal of Materials and Environmental Science, 8, 217-224. https://www.researchgate.net/publication/311724930

KIVCAK, B., MERT, T., DEMIRCI, B., BASER, K.H.C. 2001. Composition of the essential oil of Arbutus unedo L. Chemistry of Natural Compounds, 37, 445446. https://doi.org/10.1023/A:1014419309885

NUNCIO-JÁUREGUI, N., NOWICKA, P., MUNERA-PICAZO, S. HERNÁNDEZ, F., CARBONELL-BARRACHINA, A.A., WOJDYŁO, A. 2015. Identification and quantification of major derivatives of ellagic acid and antioxidant properties of thinning and ripe. Journal of Functional Foods, 12, 354-364. https://doi.org/10.1016/j.jff.2014.11.007

OLIVEIRA, I., GUEDES DE PINHO, P., MALHEIRO, R., BAPTISTA, P., PEREIRA, J.A. 2011. Volatile profile of Arbutus unedo L. fruits through ripening stage. Food Chemistry, 667-673. https://doi.org/10.1016/j.foodchem.2011.03.084

ORAK, H.H., AKTAS, T., YAGAR, H., ISBILIR, S.S., EKINCI, N., SAHIN FUSUN, H.L. 2011. Antioxidant activity, some nutritional and colour properties of vacuum dried strawberry tree (Arbutus unedo L.) fruit. Acta Scientiarum Polonorum Technologia Alimentaria, 10, 331-338.

ORAK, H.H., YAGAR, H., ISBILIR, S.S., DEMIRCI, A.S., GÜMÜŞ, T., EKINCI, N. 2011. Evaluation of antioxidant and antimicrobial potential of strawberry tree (Arbutus Unedo L.) leaf. Food Science and Biotechnology, 20, 1249-1256. https://doi.org/10.1007/s10068-011-0172-9

ÖZCAN, M.M., HACISEFEROGULLAN, H. 2007. The Strawberry (Arbutus unedo L.) fruits: Chemical composition, physical properties and mineral contents. Journal of Food Engineering, 78, 1022-1028. https://doi.org/10.1016/j.j.joodeng.2005.12.014

RE, R., PELlEGRINI, N., PROTEGGENTE, A., PANNALA, A., YANG, M., RICE-EVANS, C. 1999. Antioxidant activity applying an improved abts radical cation decolorization assay. Free Radical Biology and Medicine, 26, 1231-1237. https://doi.org/10.1016/S0891-5849(98)00315-3

RUIZ-RODRIGUEZ, B.M., MORALES, P., FERNÁNDEZ-RUIZ, V., SÁNCHEZ-MATA, M.C., CÁMARA, M., DÍEZ-MARQUÉS, C., PARDO-DESANTAYANA, M., MOLINA, M., TARDÍA, J. 2011. Valorization of wild strawberry-tree fruits (Arbutus unedo L.) through nutritional assessment and natural production data. Food Research International, 44, 1244-1253. https://doi.org/10.1016/j.foodres.2010.11.015

ZUZARTE, M., SALGUEIRO, L. 2015. Essential oils chemistry, chapter II. D.P de Sousa (ed.), Bioactive Essential Oils and Cancer. Springer International Publishing, Switzerland 2015; p. 19-29. 